\title{
Social and environmental risk management in supply chains: a survey in the clothing industry
}

\author{
Matthias Freise $^{1} \cdot$ Stefan Seuring $^{2}$
}

Received: 17 October 2013/Accepted: 12 May 2015/Published online: 21 May 2015

(C) The Author(s) 2015. This article is published with open access at Springerlink.com

\begin{abstract}
Almost daily, news indicates that there are environmental and social problems in globally fragmented supply chains. Even though conceptualisations of sustainable supply chain management suggest supplier-related risk management for sustainable products and processes as substantial for companies, research on how risk management for environmental and social issues in supply chains is performed has so far been neglected. This study aims at analysing both why companies in the clothing industry are performing management of social and environmental risks in their supply chain and what kind of action they are taking. Based on the literature on sustainable supply chain management and supply chain risk management as well as 10 expert interviews, a conceptual model for risk management in sustainable supply chains was developed. This model was tested in an empirical study in the clothing industry. The data were analysed by structural equation modelling. Results of the research show high statistical significance for the respective conceptual model. The main driver to perform risk management in environmental and social affairs is pressures and incentives from stakeholders. While companies' corporate orientation mainly drives social actions, top management drives environmental affairs for differentiating themselves from competitors.
\end{abstract}

Stefan Seuring

seuring@uni-kassel.de

Matthias Freise

Matthias.Freise@reutlingen-university.de

1 Fashion Procurement and Retail Buying, Reutlingen University, Alteburgstraße 150, 72762 Reutlingen, Germany

2 Chair of Supply Chain Management, University of Kassel, Kleine Rosenstr. 1-3, 34117 Kassel, Germany
Keywords Supply chain management · Sustainability · Risk management · Environmental and social issues · Clothing industry $\cdot$ Structural equation modelling

\section{Introduction}

Companies are more than ever exposed to a diverse set of risks in operating their supply chains [1-3]. Understanding how to perform risk management within the supply chain is important and has high priority [4]. From a traditional perspective, companies' risk is usually considered in a purely economic mode, particularly as the risk of potential asset value losses. Considering sustainability management, an extension of a company's targets and responsibilities is implied [5]. Therefore, social and environmental risks need to be included into the risk assessment besides economical risks. Related arguments are frequently made on a conceptual level in respective sustainable supply chain management literature [6].

The clothing industry with its globally fragmented and dynamic supply chains is frequently a target in media campaigns and NGO initiatives [7, 8]. There are many reports on unacceptable working conditions and environmental or ethical burdens through production and along the supply chain. Unacceptable working conditions concerning child labour, safety issues in factories, forced labour, and low minimum wages are issues as present as environmental concerns [9]. Mainly, branded apparel distributors, such as Adidas, Benetton, C\&A, Levi Strauss, and Nike, have been in the press in recent years [10]. These are indications of environmental and social risks in globally fragmented supply chains. Given the related and frequent news coverage, companies are demanded to perform risk management for sustainable supply chains, thereby also accounting 
for environmental and social issues. This provides the link back to the already mentioned literature on sustainable supply chain management.

Even though conceptualisations of sustainable supply chain management suggest supplier management and risk management for sustainable products and processes as substantial for companies [6, 11], research on how companies are or should be performing management of environmental and social risks in their supply chain has so far been neglected.

This leads to the aim of this study. It is to analyse both why companies are performing risk management of environmental and social risks in their supply chain and what kind of action they are taking.

The paper is organised as follows: In Sect. 2, a literature review on supply chain risk management and sustainable supply chain management allows the identification of overlaps among the two fields. On this basis, a conceptual model is developed. The model was tested in an empirical study. The research method is briefly outlined in Sect. 3. First, a series of expert interviews was conducted followed by a survey. The data were analysed using structural equation modelling (SEM). The findings of the survey are outlined and then discussed in Sect. 4. This allows the contribution of the paper in operationalising a sustainable supply chain risk management which is described in Sect. 5. The paper ends with a brief conclusion.

\section{Theoretical background and hypothesis development}

\subsection{Literature review}

Among the lines of research in supply chain management, both risk [1-3, 12] and sustainability [6, 11, 13] are among those topics receiving increasing attention. As a starting point, we take a brief look at the term risk and supply chain risk management. Then, we address the literature on sustainable supply chain management and subsequently assess how risk-related issues could be integrated.

For the term "risk", a generally accepted definition does not exist [3, 12]. Traditionally, risk is understood as potential economical losses or chances. In recent literature, there is a broader perspective. Risk is understood as an effect that prevents organisations to achieve its predefined targets [14]. This perspective allows extending risk from a mainly economical perspective to a sustainability perspective. Yet, these targets are extended and complemented by social and environmental targets in a sustainable context. Because much of the value creation is taking place in supply chain, the focus is also expanded from the focal company to the overall supply chain.
The literature on supply chain risk management has recently expanded, such as in the form of review papers (e.g. the recent ones by $[3,15])$ and empirical research $[16-$ 18]. In the literature on supply chain risk management (for additional reviews, see, for example, $[1,2,19,20]$ ), authors point to the fact that it is almost taken for granted that companies implement such measures to prevent any unforeseen disruptions in the supply chain [21]. We refer to the definition of supply chain risk by Pfohl et al. [3]: "Supply chain risks involve risks that can be attributed to disturbance of flow within the goods, information, and financial network, as well as the social and institutional networks. They might have negative effects on the goal achievement of single companies and the whole supply chain, respectively, with regard to end customer value, costs, time, or quality". Implementing related measures for identifying, managing, and mitigating leads then to a supply chain risk management.

It is interesting to note that none of the review papers mentioned addresses the aspects of the natural environment as well as social issues. In some cases, aspects of natural environmental risks are mentioned as a side issue. Kleindorfer and Saad [1] refer to natural and man-made disasters, whereas Pfohl et al. [3] and Rao and Goldsby [20] refer to social uncertainty, which are derived as a consequence of stakeholder demands. An indication of a field of research becoming more established is oftentimes that related literature reviews emerge. Since 2007, there has been a series of related literature reviews on sustainable supply chain management $[6,13,22]$. In many of these reviews as well as in an earlier set of papers [23, 24], risk issues play a central role. Extending the conventional risk perspective, this includes risk aspects from environmental and social issues. On the environmental side, such issues include, for example, the release of hazardous chemicals to the environment or even the inherent intoxication of workers [25]. A key issue studied is the implementation of green supply chain practices [26, 27], which has also been investigated for the textile and clothing industries [9, 28]. Such supply chain practices also extend to the social side. While some issues have already been mentioned in the introduction, worker-related aspects are the most common. Respective social standards include, for example, working hours and conditions, access to fresh water and toilets, child labour, or even forced labour. Problems of non-compliance regarding such requirements have been frequently documented in textile and clothing supply chains [25, 28, 29] and have led to the creation and implementation of related standards [30].

Overall, the risk aspect is so prominent and relevant in related research that Seuring and Müller [6] formulate one norm strategy for sustainable supply chain management, referred to as "supplier management for risk and 
performance". However, the discussion still remains open regarding the particular factors that drive such risk management and whether and how environmental and social aspects are managed differently, if risk measures for sustainable supply chains management are implemented.

The key reaction of companies in this respect is the implementation of a related risk management system. This is often driven by a rather reactive approach based on stakeholder demands [31, 32], which is also [17] the case for "conventional" risk management. However, even proactive companies might implement such a system as part of their proactive approach to sustainable supply chain management [33].

Even though it is undisputed that risk management for environmental and social affairs along the entire supply chain is essential for companies, there is no evidence what factors are driving companies to do so and how such a risk management is performed.

\subsection{Development of hypotheses and items}

The normative strategy "supplier management for risk and performance" posited by Seuring and Müller [6] serves as a starting point for the subsequent arguments. They indicate that governments, customers, and other stakeholders are driving focal companies with pressure and incentives to perform supplier evaluation for risk and performance as well as to develop sustainable products. In a Delphi study, Seuring and Müller [34] identify three key groups driving companies towards sustainable supply chain management. Customers drive related product development issues. Nongovernmental organisations (NGOs) constitute a key group and serve as representatives of a wider set of stakeholders, raising different demands than those of customers [7, 35]. Public administration acts by mandating laws or legalities, which are increasingly enforced on an international level. Particularly from a risk management perspective, the demands from NGOs [29] and legal regulations are perceived as key drivers for the implementation of environmentally and socially related risk measures, thereby companies aiming at avoiding a loss of reputation [33]. Consequently, this lays the foundations for the first two hypotheses. In theory, motivation factors could have been distinguished in the formulation of the hypothesis in the environmental and social contexts; yet in a somehow realistic perspective, this is impossible in a real-world situation. In our pre-study with 10 experts, the company managers highlighted this, so the motivation factor is seen as applicable to both environmental and social issues.

H1 The higher the pressure from NGOs, the more companies will implement supply chain-related measures for (a) environmental and (b) social risks (see Table 1).
Table 1 Single items for assessing stakeholder pressure

\begin{tabular}{ll}
\hline Item & NGO pressure \\
\hline $1 . \quad \begin{array}{l}\text { NGOs comment on environmental and social activities of our } \\
\text { company }\end{array}$ \\
2. $\quad \begin{array}{l}\text { NGOs demand that our companies comment on environmental } \\
\text { and social issues }\end{array}$ \\
3. $\quad \begin{array}{l}\text { Our company risks losing its reputation or incurring } \\
\text { competitive disadvantages if problems in compliance against }\end{array}$ \\
NGO demands or NGO agreements would be reported \\
Our company takes possible (re-)actions from stakeholders \\
into account when making decisions on environmental and \\
social issues
\end{tabular}

While the first hypothesis concentrates on NGOs, the second one focusses on legal requirements but is quite in line with the first one. Different supply chain governance structures have been discussed, driving related corporate action [36]. Such measures are in line with a long list of product- and process-related regulations, particularly within the European Union, that are regularly ensured through legal compliance audits. This is summarised in the second hypothesis.

H2 The higher the legal demand from companies, the more companies will implement supply chain-related measures for (a) environmental and (b) social risks (see Table 2).

While the first two hypotheses address the external environment, there are also proactive drivers of respective internal conduct [26, 37]. Every company has its own culture, values, and targets. These are formed by owners, management, and employees. A basic element is a written policy [38], which encourages employees towards respective conduct. One prominent example is one of the organic cotton chains, where such proactive action from both small [39, 40] and multinational companies [41] has been portrayed. Such proactivity is only achieved if environmental and social issues receive a high degree of attention and are therefore embedded into corporate culture. The communication pattern within an organisation is another essential indicator of management commitment [11]. The latter implies a long-term orientation and not just a search for easy wins and quick fixes. Hence, internal orientation for sustainability has been a further driver for such sustainability initiatives [22], leading to hypothesis 3 :

Table 2 Single items for assessing legal requirements

\begin{tabular}{ll}
\hline Item & Legal requirements \\
\hline 1. & $\begin{array}{c}\text { Products and processes of our company are influenced by legal } \\
\text { demand on environmental and social issues }\end{array}$ \\
2. & Our company regularly audits legal compliance \\
\hline
\end{tabular}


Table 3 Single items for assessing corporate orientation

\begin{tabular}{l}
\hline Item \\
\hline Corporate orientation \\
$\begin{array}{l}\text { Our company has a written policy for environmental and } \\
\text { social conducts }\end{array}$ \\
2. $\quad \begin{array}{c}\text { Our company aims at each employee comprehending the } \\
\text { relevance of environmental and social conducts }\end{array}$ \\
3. $\quad \begin{array}{l}\text { Environmental and social proactivities receive high priority } \\
\text { in our company }\end{array}$ \\
Environmental and social actions are an active part of our \\
corporate culture
\end{tabular}

H3 The higher the internal orientation of (top) management towards sustainability, the more companies will implement supply chain-related measures for (a) environmental and (b) social risks (see Table 3).

As for the respective items for testing hypotheses 3 and 4, measures of internal conduct are employed:

Yet, even proactive companies strive for competitiveness. This is a prerequisite for staying in the market in the long term, particularly in dynamic sectors [8, 29]. Such issues have also been discussed in sustainable supply chain management [42]. Inter-organisational collaboration supports impacts performance of the supply chain [43] and can therefore also be expected to contribute to risk management. Hypothesis 4 is formulated accordingly:

H4 The higher the aim of a company for competitive differentiation based on a corporate sustainability orientation, the more likely companies will implement supply chain-related measures for (a) environmental and (b) social risks.

As a specific aspect for this research and its industrial context, the risk exposure of the supply chain is taken into account, which Wiengarten et al. [8] also address for the clothing industry, relating back to the aforementioned problems (also [25, 32]). As a consequence, the information flows along the supply chain need to include environmental and social aspects leading to a greater effort not only in coordination but also to related opportunism [41]. The impacts of short product life cycles have been discussed [44], which demand the supply chain strategy to take such product-related factors into account. This provides a link back into the previously discussed aspects of corporate proactivity and competitive differentiation.

H5 The higher the risk exposure of its supply chain, the more likely companies will implement related measures for (a) environmental and (b) social risks (see Table 5).

As a further step, we need to present the items used for measuring how environmental and social risks are managed. Some items are taken up both for environmental and social issues; so, they are introduced only once. One such measure is that internal responsibility rests with a senior manager and is not delegated to a lower level of the company's hierarchy [26]. Companies might also take action in related industry initiatives.

The starting point in both cases is found in the question of what environmental and social aspects need to be monitored. For the social side, standards such as the SA 8000 offer a baseline and define criteria for work safety and conditions, health, or the right to form unions. An effect of the implementation of standards is the coordination of efforts along the supply chain [45]. Frequently, social audits are implemented, which can also be executed by third parties [46]. This risk-avoiding related measure is often combined with an active involvement in social responsible conduct [45] and might even require intensive cooperation with suppliers, where the already mentioned examples from the clothing industry can be referred to again [39-41]. This argument might even be seen as one of the starting points for the overall debate on sustainable supply chain management. On the other hand, policies need to be in place if misconduct is observed, both internally and also among suppliers [33]. Respective items are summarised in Table 6.

On the environmental side, many aspects mirror those on the social side, such as top management support and the active engagement in interest groups.

A key question concerns product characteristics and therefore product development. Restricted substances might be shortlisted as life cycle assessment-based data and toxicity-related information would be used for determining impacts along the supply chain [47]. In sourcing materials and pre-products, environmental criteria have to be fulfilled not only in terms of the used materials and parts but also by the respective processes at the suppliers. This implies that monitoring has to cover the materials as well as the suppliers. Again, third parties might be employed for monitoring respective conduct regarding related processes. Last but not least, suppliers not fulfilling the related requirements risk being delisted and removed from the supply chain. The issues discussed are summarised in the items in Table 7.

Bringing all the arguments together allows conceptualising environmental and social risk-related drivers and measures, as shown in Fig. 1.

\section{Survey methodology}

In order to test the hypotheses and the model, we conducted a survey within the European clothing and apparel industry. First, to optimise the final model, the construct conceptualisation, and the measurement models, we 
performed a series of semi-structured interviews with 10 clothing industry experts from the industry, consulting, and academia. All related aspects of supply chain management, risk management, and sustainability were addressed. The upfront developed construct conceptualisation and operationalisation were readjusted to conform to the final model. Pretest data were collected, and a very first evaluation of measurement models and the structural model was performed. Finally, some indicators of the measurement models were adjusted based on the evaluation of the pretest data.

For data collection, a survey at four value-added steps within the European clothing industry was performed. The questionnaire consisted of 34 questions (see the items listed in Tables 1, 2, 3, 4, 5, 6, 7) and applied six-point Likert scales, where the larger value represents strong agreement with respect to each measurement variable while the smaller value represents strong disagreement. We used an equal-point Likert scale to encourage respondents to give a clear indication instead of constant average answers. Content validity of the questionnaire was assured [48] as the questions (indicators), their formulation, and scaling had been intensely discussed in expert interviews. The questionnaire was sent out to 292 persons in companies by personalised emails. Only one person per company was approached. All companies have activities in at least one of the value-adding steps: (1) production of fabric, (2) production of apparel, (3) owning a brand or (4) retailing. The overall supply chain is typically run by a brand owner, which fulfils all criteria of a focal company, such as designing the product, being visible to the customer as well as managing the supply chain. The companies approached are located in five European countries (Germany, Poland, Switzerland, Turkey, and the Netherlands). Each of them is driving a global supply chain. Addresses were collected by studying trade journals and from upfront personal approaches by telephone. We received 92 useful responses; therefore, we had a response rate of $31.5 \%$. The response rate was achieved only by sending personal emails and, where possible, providing a reminder by phone. Respondents are mainly part of the first and second management levels. Thirty-five per cent of all respondents are members of the top management; $43 \%$ belong to the second management level. Two and a half per cent of respondents did not give an indication of their management level, and the remaining part $(19.5 \%)$ is respondents from lower management. The distribution of management levels of the respondents is in line with the sample approached. The size of companies responding represents the structure of this sector. Twenty-six per cent achieve a yearly turnover from $€ 1$ to 10 million, $22 \%$ in the range from $€ 10$ to $50 \mathrm{M}$, $28 \%$ from $€ 50$ to $500 \mathrm{M}$, and $22 \%$ achieve more than $€ 500 \mathrm{M}$ annual turnover.

For data analysis, a structural equation analysis was performed. Covariance- and variance-based methods are available for the estimation of the model. Covariancebased methods are the most popular for estimating structural equation models [49] but have high prerequisites concerning theory, data, and the operationalisation of latent variables [50, 51]. The advantage of covariance-based methods is easy-to-handle, simple goodness-of-fit measures. The variance-based partial least square (PLS)

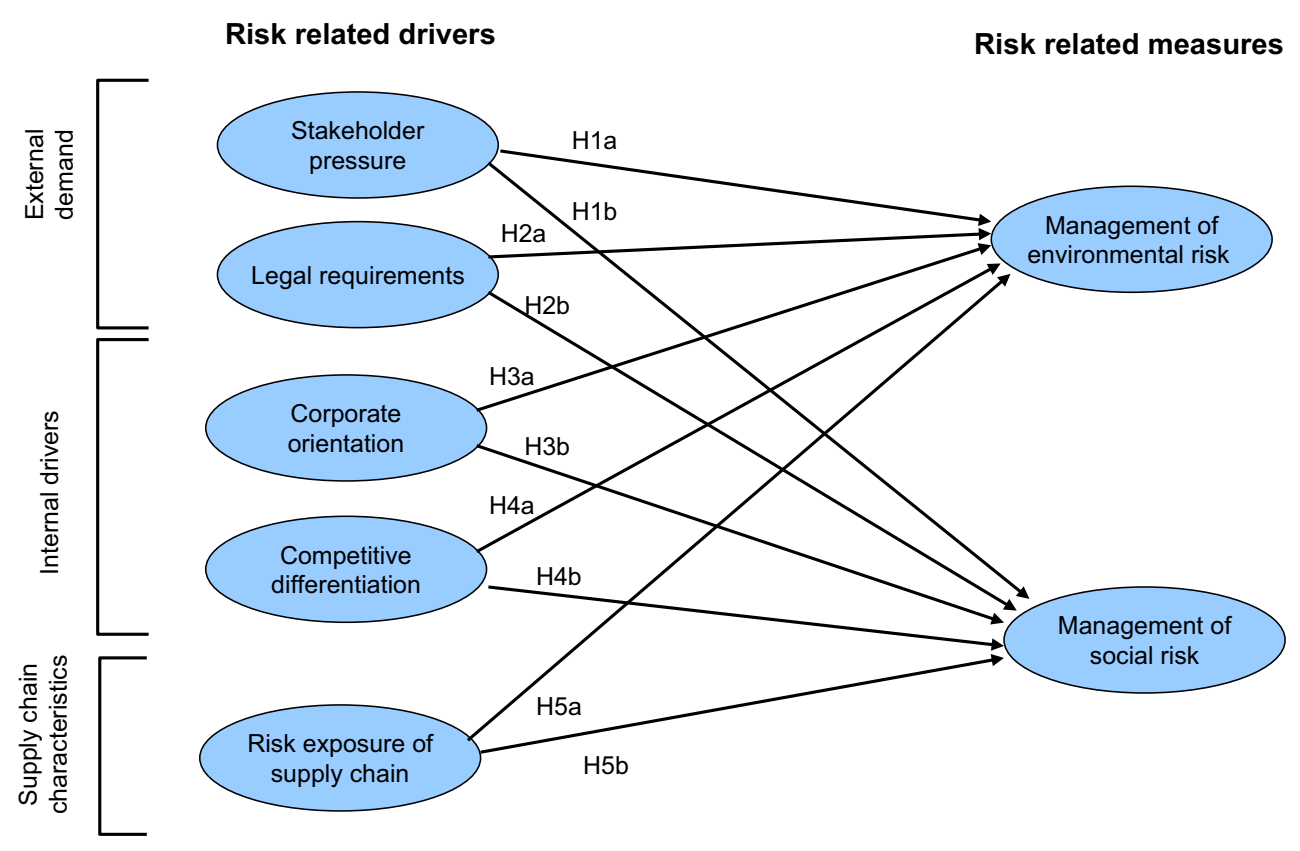

Fig. 1 Model of environmental and social risk-related drivers and measures 
Table 4 single items for assessing competitive differentiation Item Competitive differentiation

1. Our company communicates its activities for environmentally and socially sound products and conducts into the market

2. Our company distinguishes itself from competitors by means of its clear positioning towards environmentally and socially sound products and processes

Table 5 Single items for assessing risk exposure of the supply chain Item Risk exposure of the supply chain

1. Our company organises global supply chains

2. A high degree of information has to be coordinated for our business activities

3. The uncertainty resulting from the multitude of actors and products is a typical element of the business activities of our company

4. The products of our company have a short product life cycle (short use phase)

Table 6 Social risk measures

Item Management of social risk

1. A senior manager is responsible for managing social risks

2. Our company plays an active role in social interest groups/ NGOs

3. A code of conduct or similar standard such as SA 8000 is implemented and has to be obeyed for all business activities

4. Our company conducts social audits at suppliers or employs a third party for such audits

5. Our company offers incentives for suppliers if they engage in social responsible conduct

6. Our company cooperates with business partners beyond the first tier towards improving social (working) conditions along the supply chain

7. Our company has policies in place for taking action if social misconduct (at suppliers) is documented

method has advantages when sample sizes are small, the data are non-normally distributed, or non-convergent results are likely because complex models with many variables and parameters are estimated [52]. The disadvantage is that the PLS method does not provide a simple goodnessof-fit measure. That means that, applying the PLS algorithm requires an extensive model evaluation. We used the variance-based partial least square (PLS) method because conceptualisation of risk management in sustainable supply chains is so far still under research, sample size can be smaller than in covariance-based methods, and models with many indicators can be estimated. Therefore, the disadvantages of missing global goodness-of-fit measures and
Table 7 Environmental risk measures

Item Management of environmental risk

1. A senior manager is responsible for managing environmental risks

2. Our company plays an active role in environmental interest groups

3. There are requirements for product development, specifying environmental criteria of products

4. There is a list of restricted substances as part of the product design specifications for sourced materials, which must be obeyed

5. Product life cycle assessments (LCA) are an integral part of product evaluation in our company

6. Only environmentally certified materials are to be used

7. During product design, material samples are tested towards being environmentally sound, thus avoiding environmental problems

8. Environmental criteria play a key role in supplier selection and evaluation

9. Our company conducts environmental audits at suppliers or employs third parties for such audits

10. Our company has policies in place for taking action if environmental misconduct (at suppliers) is documented

complex model evaluations were accepted. The evaluation of the measurement models and the structural model was performed against criteria as suggested by [50, 53]. As a software tool, we used SmartPLS version: 2.0 M3 (beta) [54].

For performing model estimation with PLS, the minimum requirement of the sample size is 10 times the highest number of exogenous constructs loading on endogenous constructs [51]. The highest number of exogenous constructs used in one construct of the hypotheses was five. Therefore, the sample size of 92 is adequate for using the PLS method.

\section{Results of model estimation}

The results of the model estimation are illustrated in Fig. 2 and presented subsequently.

\subsection{Evaluations of model quality}

Applying the PLS algorithm requires an extensive model evaluation. Our evaluation is oriented on the catalogue of adequate, nonparametric quality criteria of Chin [55]. Furthermore, we followed typical suggestions $[50,51]$ so that the model evaluation follows a multilevel process. Only if latent variables are reliably estimated does the evaluation of the structural model make sense. Therefore, the measurement model is evaluated first followed by the evaluation of the structural model. 
Fig. 2 Estimated structural model

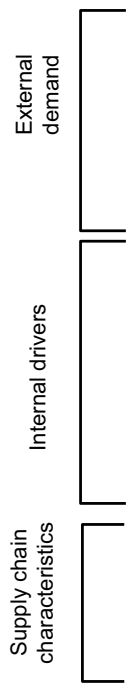

Risk related drivers

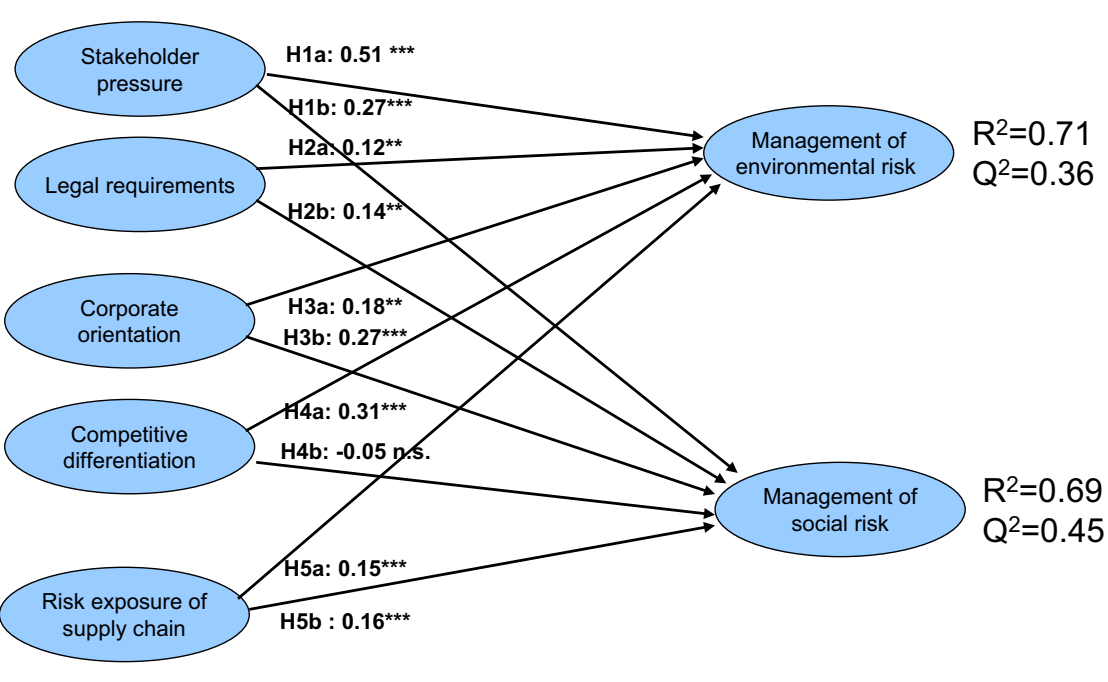

\subsection{Evaluation of measurement models}

A measurement model specifies the relationship between observable variables and the underlying construct. All constructs are reflectively operationalised. Several criteria are discussed for the evaluation of reflective constructs. According to typical suggestions $[50,51,53]$, we evaluated the reliability of the measurement models using indicator reliability, construct reliability, convergent validity, and discriminant validity.

Indicator reliability specifies how much of an indicator's variance can be explained by the underlying latent variable. It is demanded that more than $50 \%$ of an indicator's variance is explained by the latent construct. Its value is the square of the item loading [50]. That means that, for item loadings of the latent constructs on an indicator variable, square of the indicator loading larger than 0.7 is acceptable $[50,51]$. Other authors suggest that an indicator loading of 0.4 is acceptable [50] what equals a square of the indicator loading of 0.64. Indicator loadings less than 0.4 should be eliminated from measurement models [56]. In our study, the indicator loadings ranged between 0.68 and 0.97 ; in other words, the lowest indicator's explained variance was just below 0.5 but above 0.4 . This indicator was therefore not deleted. This implies that we find support for indicator reliability.

Construct reliability discovers whether a construct is adequately measured by its indicators [50]. This requires that indicators assigned to the same construct jointly measure the construct adequately [57]. Therefore, composite reliability can be used to check how well a construct is measured by its assigned indicators [51]. A good threshold is composite reliability being larger than 0.6 [50]. All values are larger than 0.6 as required (see Table 8).
Table 8 Average variance extracted, composite reliability, and Cronbach's alpha

\begin{tabular}{llll}
\hline Construct & $\begin{array}{l}\text { Average } \\
\text { variance } \\
\text { extracted }\end{array}$ & $\begin{array}{l}\text { Composite } \\
\text { reliability }\end{array}$ & $\begin{array}{l}\text { Cronbach's } \\
\text { alpha }\end{array}$ \\
\hline Stakeholders & 0.78 & 0.93 & 0.90 \\
$\begin{array}{l}\text { Legal requirements } \\
\text { Corporate orientation }\end{array}$ & 0.79 & 0.88 & 0.74 \\
$\quad \begin{array}{l}\text { Competitive differentiation } \\
\text { Risk exposure of }\end{array} \quad 0.93$ & 0.96 & 0.93 \\
$\quad$ supply chain & 0.71 & 0.91 & 0.86 \\
$\quad \begin{array}{l}\text { Management of } \\
\text { environmental risk }\end{array}$ & 0.53 & 0.90 & 0.87 \\
$\quad$ Management of social risk & 0.64 & 0.93 & 0.91 \\
\hline
\end{tabular}

Additionally, a commonly used measure for construct validity is Cronbach's alpha. The latter quantifies how well a set of indicators measures the construct. An indicator set is only useable if Cronbach's alpha exceeds 0.7 [53]. Rossiter considers very high values as problematic because this could be a sign that content or linguistic validity of indicators is congruent. Therefore, an ideal value for Cronbach's alpha is 0.8 [58]. Therefore, we double-checked for linguistic congruence by the experts' discussions. All values of Cronbach's alpha in our model exceed 0.7 which indicates that we are sure that the indicator set measures the construct quite well (see Table 8).

Convergent validity assesses the correlation between responses obtained by maximally different methods measuring the same construct [51]. It can be measured by the average variance extracted (AVE), which measures the variance of its indicators captured by the construct relative to the total variance. A common threshold value of 
Table 9 AVE and squared correlations

\begin{tabular}{|c|c|c|c|c|c|c|c|}
\hline Construct & $\begin{array}{l}\text { Competitive } \\
\text { differentiation }\end{array}$ & Stakeholders & $\begin{array}{l}\text { Legal } \\
\text { requirements }\end{array}$ & $\begin{array}{l}\text { Corporate } \\
\text { orientation }\end{array}$ & $\begin{array}{l}\text { Management } \\
\text { of social risk }\end{array}$ & $\begin{array}{l}\text { Risk exposure of } \\
\text { the supply chain }\end{array}$ & $\begin{array}{l}\text { Management of } \\
\text { environmental } \\
\text { risk }\end{array}$ \\
\hline $\begin{array}{l}\text { Competitive } \\
\text { differentiation }\end{array}$ & 0.93 & & & & & & \\
\hline Stakeholders & 0.47 & 0.78 & & & & & \\
\hline Legal requirements & 0.26 & 0.29 & 0.79 & & & & \\
\hline Corporate orientation & 0.49 & 0.32 & 0.38 & 0.77 & & & \\
\hline Management of social risk & 0.36 & 0.58 & 0.39 & 0.46 & 0.64 & & \\
\hline $\begin{array}{l}\text { Supply chain } \\
\text { characteristics }\end{array}$ & 0.09 & 0.19 & 0.22 & 0.23 & 0.31 & 0.71 & \\
\hline $\begin{array}{l}\text { Management of } \\
\text { environmental risk }\end{array}$ & 0.53 & 0.51 & 0.37 & 0.49 & 0.53 & 0.26 & 0.64 \\
\hline
\end{tabular}

All AVE values are greater than the squared correlations of the latent variables

Table 10 Path coefficients and $t$ values

\begin{tabular}{lllcl}
\hline Hypothesis & Endogenous construct & Exogenous construct & Path coefficient & $t$ value \\
\hline H1b & Social risk & NGOs & 0.51 & $5.56^{* * *}$ \\
H1a & Environmental risk & NGOs & 0.27 & $3.15^{* * *}$ \\
H2b & Social risk & Legal requirements & 0.14 & $1.74 * *$ \\
H2a & Environmental risk & Legal requirements & 0.12 & $1.72^{* *}$ \\
H3b & Social risk & Corporate orientation & 0.27 & $2.26^{* * *}$ \\
H3a & Environmental risk & Corporate orientation & 0.18 & $1.73^{* *}$ \\
H4b & Social risk & Competitive differentiation & -0.05 & 0.42 n.s. \\
H4a & Environmental risk & Competitive differentiation & 0.31 & $3.07 * * *$ \\
H5b & Social risk & Risk exposure of the supply chain & 0.16 & $2.83^{* * *}$ \\
H5a & Environmental risk & Risk exposure of the supply chain & 0.15 & $2.42^{* * *}$ \\
\hline
\end{tabular}

$* * p>0.1 ; * * * p>0.05$

AVE $>0.5$ confirms that at minimum, half of the variance of indicator is explained by the underlying latent variable [50, 51, 59].

Discriminant validity describes whether the constructs are really independent. For testing discriminant validity, AVE can also be used. Discriminant validity is proven if the AVE of a latent variable is greater than the squared correlations of this latent variable with any other of the model's constructs [59]. In Table 9, AVE values are illustrated in bold; the squared correlations are in the diagonal thereunder.

\subsection{Evaluation of the structural equation model}

The evaluation of the structural model is based on several criteria, reflecting the path coefficients in the structural model and their significance, the coefficient of determination $\left(R^{2}\right)$, the effect size $f^{2}$, and prediction relevance.

The path coefficients represent standardised beta-coefficients resulting from the least-squares estimation. The power of the exogenous constructs is evaluated by the standardised path coefficients. According to Chin [55], a substantial relation can be considered from values larger than 0.2. Lohmöller [60] considers relations larger than 0.1 already as relevant.

Due to missing distributional assumptions of the sample set, a parametric test of significance cannot be performed in PLS. The bootstrapping method provides the possibility to substitute the theoretical distribution function by the empirical distribution function of the sample [53]. With the empirical distribution of estimated average on the sample and variance, the null hypothesis can be tested with a $t$ test, determining that estimated path coefficients are significantly different from null [53]. The level of significance with $t$ values $>1.65$ is larger than $90 \%$ and with $t$ values $>1.96$ is larger than $95 \%$. To avoid instable $t$ values, the bootstrapping procedure was performed with 2000 samples (see Table 10).

A substantial relation for hypotheses H1a, H1b, H3b, and $\mathrm{H} 4 \mathrm{a}$ can be considered with values $>0.2$. For hypotheses $\mathrm{H} 2 \mathrm{a}, \mathrm{H} 2 \mathrm{~b}, \mathrm{H} 3 \mathrm{a}, \mathrm{H} 5 \mathrm{a}$, and $\mathrm{H} 5 \mathrm{~b}$, a relevant relation with values $>0.1$ could be observed. We could not observe a relation for hypothesis $\mathrm{H} 4 \mathrm{~b}$. The corresponding $t$ values indicate a satisfactory level of significance. 
Table 11 Effect sizes $\left(f^{2}\right)$

\begin{tabular}{lll}
\hline Constructs & $\begin{array}{l}\text { Management of } \\
\text { environmental } \\
\text { risk }\end{array}$ & $\begin{array}{l}\text { Management } \\
\text { of social risk }\end{array}$ \\
\hline NGOs & 0.0596 & 0.2348 \\
Legal requirements & 0.0229 & 0.0040 \\
Corporate orientation & 0.0092 & 0.0567 \\
$\begin{array}{l}\text { Competitive differentiation } \\
\text { Risk exposure of the }\end{array}$ & 0.0963 & 0.0243 \\
$\quad$ supply chain & 0.2890 & 0.0607 \\
\hline
\end{tabular}

Table 12 Values of Stone-Geisser criterion $\left(\mathrm{Q}^{2}\right)$

\begin{tabular}{ll}
\hline Construct & $\mathrm{Q}^{2}$ \\
\hline Management of environmental risk & 0.3584 \\
Management of social risk & 0.4521 \\
\hline
\end{tabular}

$R^{2}$ reflects the level or share of the latent constructs' explained variance [53]. According to Chin [49], $R^{2}$ values of $0.66,0.33$, and 0.19 in PLS path models can be interpreted as substantial, moderate, and weak, respectively. The coefficients of determination $\left(R^{2}\right)$ in our study are 0.71 for the management of environmental risk and 0.69 for the management of social risk (see Fig. 2), respectively. From these results, we conclude a substantial explanatory power of our model.

For each effect in the path model, the effect size $f^{2}$ is calculated as the increase in $R^{2}$ relative to the proportion of variance of the latent variable that remains unexplained. According to Chin [50], $f^{2}$ values of $0.02,0.15$, and 0.35 imply small, medium, and large effects, respectively. Typically, as the $f^{2}$ values are not directly displayed in SmartPLS, they were calculated according to the suggestions $[50,53]$. Table 11 shows the effect sizes $\left(f^{2}\right)$ between the constructs.

The model's predictive validity can be tested with the Stone-Geisser test [49]. The Stone-Geisser criterion $\mathrm{Q}^{2}$ was determined with the blindfolding procedure. The model is considered to have predictive validity if $\mathrm{Q}^{2}$ is larger than 0 [55]. This supports that the observed values are well reconstructed, and that the model has predictive relevance (see Table 12).

\section{Findings}

The findings of the structural equation analysis can be interpreted accordingly. The main drivers for companies to manage environmental and social risks are pressures and incentives from stakeholders, particularly NGOs (H1a and
H1b confirmed). Other than pure economic-driven risk management, which is intended to secure companies' financial targets, environmental and social aspects reflect the extension of relevant stakeholders in sustainable supply chain management as summarised [6]. Hence, sustainable operations are closely linked to stakeholder management. In order to avoid negative reports, loss of reputation, and therefore competitive disadvantage, companies try to present a positive image to their stakeholders. This extends to incorporating potential stakeholder reactions into business decisions. Legal requirements are only weak drivers for social and environmental risk management activities ( $\mathrm{H} 2 \mathrm{a}$ and $\mathrm{H} 2 \mathrm{~b}$ confirmed with low path coefficients). A substantial influence could neither be observed for the management of social risk nor for environmental risk. As already expected after having conducted the expert interviews, the effect of legal requirements is dominated by other drivers. Our survey results show that companies strictly comply with legal regulation. Other drivers, such as stakeholder pressure and internal orientation, imply higher social and environmental standards. Legal regulation just ensures that companies fulfil compliance-driven minimum requirements. This result allows a better comprehension of the issue, namely that overall NGOs have more impact on companies' actions. In the Delphi study [34], there was no consistence evident between researchers and NGO experts' opinion towards this question. Our study shows a considerably higher influence of stakeholders and NGO pressure on companies.

Corporate orientation significantly impacts the management of social risk ( $\mathrm{H} 3 \mathrm{~b}$ confirmed). Contrastingly, there is only a weak effect of corporate orientation on the management of environmental risk (H3a confirmed with low path coefficient). Companies with significant activities in risk management for social affairs are stating the importance of social action for owners and employees in a written management commitment. In these companies, social action is part of corporate culture and has a high priority in daily business. In our preparative expert interviews, one of the experts stated that if there is no corporate orientation towards sustainability, all sustainable action is green washing. Even though our survey is not a confirmation of this argument, it shows that corporate orientation is at least a prerequisite for integrating social measures into supply chain management. As we could observe, there is only a weak impact of corporate orientation on the management of environmental risk. This needs to be explained differently, which is done below.

There is strong support for companies aiming at competitive differentiation to be engaging in the management of environmental risk (H4a confirmed). Yet, it could not be observed that companies implement activities to manage social risk as a means of corporate differentiation $(\mathrm{H} 4 \mathrm{~b}$ 
rejected). Consumers buying clothing are more aware of hazardous substances in textiles than of social conditions in the supply chain. There is an attitude behaviour gap evident [61] as was confirmed in the expert interviews. In our survey, we could notice this gap as companies are focussing on differentiation based on environmental criteria. They actively communicate these differences and safeguard environmental criteria in the form of intense risk management for environmental affairs within their corporation and the whole supply chain.

Rather surprising is the fact that the global fragmentation of the clothing industry and the related perception of being highly exposed to social and environmental risks are only weak drivers for risk management activities (H5a and H5b confirmed with low path coefficients). A high incidence rate of damaging events, which is indicated by global trade flows, complex supply chains with more information overcharging supply chain members, and short product life cycles, does not trigger companies to manage this social or environmental risk with high priority. One could argue that managers responsible for supply chain activities are not aware of the implied risks. However, it is evident that media and NGOs are stressing the implicated risk almost daily, and our experts stated their risk awareness as well. Nonetheless, companies see themselves in a competitive position where a cost-efficient supply chain is the dominant prerequisite. Companies in a highly competitive industry seem to favour economic performance over social or environmental issues, particularly if there was a conflict among related performance criteria.

\section{Discussion}

The contribution of the paper is threefold: First, it extends previous research on supply chain risk management. This is dominated by listing certain risk issues [2] and risk practices [17] and assessing their performance implications [16]. The aspect of why companies perform risk management seems surprisingly neglected. In the economically driven case, it seems quite obvious that risk management is implemented in order to avoid supply chain disruption, quality issues, and similar effects, thereby staying competitive and avoiding financial losses. In many cases, shareholders can have similar demands to NGOs, demanding economically based risk management along the supply chain. This would require additional empirical research, but the factors identified and their relevance would be quite similar. The role of shareholders, who form one particular set of stakeholders, would have to be emphasised. However, internal orientation and striving for competitiveness are well in line with previous suggestions from conceptual research [12].
Second, there is the major conceptual contribution of this paper. While risk management in sustainable supply chains has been mentioned quite often [6], a respective conceptualisation has been missing so far. The five constructs (stakeholder pressure, legal pressure, internal orientation, competitiveness, and risk exposure) are quite general; however, they comprehend the major forces driving the management of environmental and social risks in supply chains. This is specified in the items used for measuring the constructs, which extends, for example, the norm strategy of Seuring and Müller [6] and sheds light on what drives related risk management measures. Further, the particular indicators used within this study specify the constructs of risk management. The focus on environmental and social risks seems justified as concentrating on them allowed a shorter questionnaire.

The third contribution of the paper is based on the empirical research. Hence, the model is not only developed but also tested in a survey applying structural equation modelling. There are some key points of the empirical research that warrant discussion. While previous research also emphasised the relevance of legal requirements, such as the Delphi study of Seuring and Müller [34], where they are seen as being of equal relevance to stakeholder pressure, the findings from this research seem more straightforward. Legal demands rather form a kind of baseline that has to be met regardless. In international operations and supply chains, which are particularly relevant for the clothing sector studied here but would also hold for many other sectors, these legal demands are only partly relevant. Legal requirements of one particular country or even the European Union are only enforceable within their borders. Contrastingly, companies perceive NGO pressure as much more relevant [11]; this is labelled as "reconceptualising the supply chain". The difference observed among environmental and social risks is somewhat surprising and has not been suggested in previous empirical research [24]. Recent examples and news coverage provide evidence of such pressure for both aspects, which leaves some questions open for future research, where this could be analysed in detail.

The differences in corporate orientation and competitive differentiation seem to be easier to comprehend. Corporate orientation is more relevant for managing social risks. Here, we might have some sector-specific impact as social issues are highly relevant for the clothing industry. The findings for competitive differentiation are well in line with previous research. Win-win situations are found among the environmental and economic dimensions of sustainability, while trade-offs among the social and economic dimensions seem to be harder to overcome [6].

A last word should be spent on the managerial relevance of the research. Supply chain managers have been among 
those answering the survey questionnaire. They should find the insights useful as there are strong demands for the integration of sustainability criteria into supply chain management. Our results may help them to focus these discussions and offer guidance to managing environmental and social risks in their supply chain. While the factors studied show some differences, the overall success would depend on integrating all of them. In related literature, authors suggest that collaboration with stakeholders (here NGOs) is essential for managers [62, 63]. This study provides evidence that NGOs have a high impact on companies' actions. As a managerial implication, the result indicates that companies have to take both the internal and the external drivers into account to establish related measures.

\section{Conclusions}

The paper offers an empirical study on risk management in sustainable supply chains. This is operationalised by assessing external, i.e. stakeholder and legal pressure, as well as internal orientation and competitiveness drivers for implementing measures towards managing environmental and social risks in supply chains. The findings emphasise the impact of stakeholder pressure on companies and their supply chains. Yet, the survey-based research also finds strong evidence for the self-interest and self-motivation of companies in moving towards sustainable supply chain management by reducing environmental and social risks.

One key suggestion for future research is to extend the empirical study to other parts of the world, particularly Asia, where most of the clothing industry factories are located. This future research should (1) yield interesting insight into managers' perceptions in respective countries and (2) allow comparison to this European-based study. A second extension of the extant research would address different industrial sectors. This should also provide more detailed insight into the influence of risk exposure.

Finally yet importantly, one of the deliberate omissions of this research would also be worthwhile to study, which is the intersection or interplay of environmental and social risks with economic risks. While the evidence found here, addressing this intersection in a separate study seems promising and would deepen insights into supply chain risk management.

Open Access This article is distributed under the terms of the Creative Commons Attribution 4.0 International License (http:// creativecommons.org/licenses/by/4.0/), which permits unrestricted use, distribution, and reproduction in any medium, provided you give appropriate credit to the original author(s) and the source, provide a link to the Creative Commons license, and indicate if changes were made.

\section{References}

1. Kleindorfer P, Saad G (2005) Managing disruption risks in supply chains. Prod Oper Manag 14(1):53-68

2. Tang C (2006) Perspectives in supply chain risk management. Int J Prod Econ 103(2):451-488

3. Pfohl H, Köhler H, Thomas D (2010) State of the art in supply chain risk management research: empirical and conceptual findings and a roadmap for the implementation in practice. Logist Res 2(1):33-44

4. Manuj I, Mentzer JT (2008) Global supply chain risk management strategies. Int J Phys Distrib Logist Manag 3:192-223

5. Halldórsson A, Kotzab H, Skjøtt-Larsen T (2009) Supply chain management on the crossroad to sustainability: A blessing or a curse? Logist Res 1(2):83-94

6. Seuring S, Müller M (2008) From a literature review to a conceptual framework for sustainable supply chain management. J Clean Prod 16(15):1699-1710

7. Emmelhainz M, Adams R (1999) The apparel industry response to "sweatshop" concerns: AQ review and analysis of codes of conduct. J Supply Chain Manag 35(3):51-57

8. Wiengarten F, Pagell M, Fynes B (2012) Supply chain environmental investments in dynamic industries: comparing investment and performance differences with static industries. Int $\mathbf{J}$ Prod Econ 135(2):541-551

9. Baskaran V, Nachiappan S, Rahman S (2012) Indian textile suppliers' sustainability evaluation using the grey approach. Int $\mathrm{J}$ Prod Econ 135(2):647-658

10. Spar D, Mure L (2003) The power of activism: assessing the impact of NGOs on global business. Calif Manag Rev 45(3):78-101

11. Pagell M, Wu Z (2009) Building a more complete theory of sustainable supply chain management using case studies of 10 exemplars. J Supply Chain Manag 45(2):37-56

12. Jüttner U, Peck H, Christopher M (2003) Supply chain risk management: outlining an agenda for future research. Int J Logist Res Appl 6(4):197-210

13. Carter C, Easton P (2011) Sustainable supply chain management: evolution and future directions. Int J Phys Distrib Logist Manag 41(1):46-62

14. Bagozzi RP, Yi Y (1988) On the evaluation of structural equation models. J Acad Mark Sci 16:74-94

15. Colicchia C, Strozzi F (2012) Supply chain risk management: a new methodology for a systematic literature review. Supply Chain Manag Int J 17(4):403-418

16. Wagner SM, Bode C (2008) An empirical examination of supply chain performance along several dimensions of risk. J Bus Logist 29(1):307-325

17. Thun J, Hoenig D (2011) An empirical analysis of supply chain risk management in the German automotive industry. Int J Prod Econ 131(1):242-249

18. Blome C, Schoenherr T (2011) Supply chain risk management in financial crises - a multiple case-study approach original research article. Int J Prod Econ 134(1):43-57

19. Khan O, Burnes B (2007) Risk and supply chain management: creating a research agenda. Int J Logist Manag 18(2):197-216

20. Rao S, Goldsby T (2009) Supply chain risks: a review and typology. Int J Logist Manag 20(1):97-123

21. Trkman P, McCormack K (2009) Supply chain risk in turbulent environments. A conceptual model for managing supply chain network risk. Int J Prod Econ 119(2):247-258

22. Gold S, Seuring S, Beske P (2010) Sustainable supply chain management and inter-organizational resources: a literature review. Corp Soc Responsib Environ Manag 17(4):230-245 
23. Cousins PD, Lamming RC, Bowen F (2004) The role of risk in environment-related supplier initiatives. Int J Oper Prod Manag 24(6):554-565

24. Teuscher P, Grüninger B, Ferdinand N (2006) Risk management in sustainable supply chain management (SSCM): lessons learnt from the case of GMO-free soybeans. Corp Soc Responsib Environ Manag 13(1):1-10

25. Preuss L (2001) In dirty chains? Purchasing and greener manufacturing. J Bus Ethics 34(3-4):345-359

26. Zhu Q, Sarkis J, Lai KH (2008) Confirmation of a measurement model for green supply chain management practices implementation. Int J Prod Econ 111(2):261-273

27. Beske P (2012) Dynamic capabilities and sustainable supply chain management. Int $\mathrm{J}$ Phys Distrib Logist Manag 42(4):372-387

28. Caniato F, Caridi M, Crippa L, Moretto A (2012) Environmental sustainability in fashion supply chains: an exploratory case based research. Int J Prod Econ 135(2):659-670

29. de Brito MP, Carbone V, Meunier Blanquart CM (2008) Towards a sustainable fashion retail supply chain in Europe: organisation and performance. Int J Prod Econ 114(2):534-553

30. Müller M, Gomes dos Santos V, Seuring S (2009) The contribution of environmental and social standards towards ensuring legitimacy in supply chain governance. J Bus Ethics 89(4):509-523

31. Roberts S (2003) Supply chain specific? Understanding the patchy success of ethical sourcing initiatives. J Bus Ethics 44(2):159-170

32. Mamic I (2005) Managing global supply chain: the sports footwear, apparel and retail sectors. J Bus Ethics 59(1-2):81-100

33. Koplin J, Seuring S, Mesterharm M (2007) Incorporating sustainability into supply policies and supply processes in the automotive industry - the case of Volkswagen. J Clean Prod 15(11):1053-1062

34. Seuring S, Müller M (2008) Core issues in sustainable supply chain management-a Delphi study. Bus Strategy Environ 17(8):455-466

35. Ageron B, Gunasekaran A, Spalanzani A (2012) Sustainable supply chain management: an empirical study. Int J Prod Econ 140(1):168-182

36. Vermeulen WJV, Kok MTJ (2012) Government interventions in sustainable supply chain governance: experience in Dutch frontrunning cases. Ecol Econ 83:183-196

37. Wu GC, Ding JH, Chen PS (2012) The effects of GSCM drivers and institutional pressures on GSCM practices in Taiwan's textile and apparel industry. Int J Prod Econ 135(2):618-636

38. Kolk A (2005) Corporate social responsibility in the coffee sector: the dynamics of MNC responses and code development. Eur Manag J 23(2):228-236

39. Meyer A, Hohmann P (2000) Other thoughts; other results? Remei's bioRe organic cotton on its way to the mass market. Greener Manag Int 31:59-70

40. Kogg B (2003) Greening a cotton-textile supply chain: a case study of the transition towards organic production without a powerful focal company. Greener Manag Int 43:53-64

41. Goldbach M, Seuring S, Back S (2003) Coordinating sustainable cotton chains for the mass market. Greener Manag Int 43:65-78

42. Svensson G (2007) Aspects of sustainable supply chain management (SSCM): conceptual framework and empirical example. Supply Chain Manag Int J 12(4):262-266
43. Vachon S, Klassen R (2008) Environmental management and manufacturing performance: the role of collaboration in the supply chain. Int J Prod Econ 111(2):299-315

44. Aitken J, Childerhouse P, Towill D (2003) The impact of product life cycle on supply chain strategy. Int $\mathrm{J}$ Prod Econ 85(2): 127-140

45. Ciliberti F, de Groot G, de Haan J, Pontrandolfo P (2009) Codes to coordinate supply chains: SMEs' experiences with SA8000. Supply Chain Manag Int J 14(2):117-127

46. Kortelainen K (2008) Global supply chains and social requirements: case studies of labour condition auditing in the People's Republic of China. Bus Strategy Environ 17(7):431-443

47. Seuring S (2011) Supply chain management for sustainable products-insights from research applying mixed-methodologies. Bus Strategy Environ 20(7):471-484

48. Malhotra M, Grover V (1998) An assessment of survey in POM: from construct to theory. J Oper Manag 16(4):407-425

49. Chin WW (1998) Issues and opinion on structural equation modelling. Manag Inf Syst Q 22(1):7-16

50. Ringle C, Spreen F (2007) Beurteilung der Ergebnisse von PLSPfadanalysen. Das Wirtschaftsstudium 36(2):211-216

51. Götz O, Liehr-Gobbers K, Krafft M (2010) Evaluation of structural equation models using the partial least squares (PLS) approach. In: Esposito Vinzi V, Chin WW, Henseler J, Wang H (eds) Handbook of partial least squares. Springer handbooks of computational statistics. Springer Berlin, pp 691-711

52. Henseler J, Ringle CM, Sinkovics RR (2009) The use of partial least squares path modeling in international marketing. Adv Int Mark 20:277-319

53. Weiber R, Mühlhaus D (2010) Strukturgleichungsmodellierung. Springer, Berlin

54. Ringle CM, Wende S, Will A (2005) SmartPLS 2.0 (beta), Hamburg

55. Chin WW (1998) The partial least squares approach to structural equation modeling. In: Marcoulides GA (ed) Modern methods for business research. Psychology Press, New York, pp 295-336

56. Hulland J (1999) Use of partial least squares (PLS) in strategic management research: a review of four recent studies. Strategy Manag J 20(4):195-204

57. Bagozzi RP, Baumgartner H (1994) The evaluation of structural equation models and hypothesis testing. In: Bagozzi RP (ed) Principles of marketing research. Blackwell, Cambridge, pp 386-422

58. Rossiter J (2002) The C-OAR-SE procedure for scale development in marketing. Int J Res Mark 19:305-335

59. Fornell C, Larcker DF (1981) Evaluating structural equation models with unobservable variables and measurement errors. J Mark Res 18:39-50

60. Lohmöller J (1989) Latent variable path modeling with partial least squares. Physica, Heidelberg

61. Padel S, Foster C (2005) Exploring the gap between attitudes and behaviour: understanding why consumers buy or do not buy organic food. Br Food J 107(8):606-625

62. Meixell MJ, Luoma P (2015) Stakeholder pressure in sustainable supply chain management: a systematic review. Int J Phys Distrib Logist Manag 45(1/2):69-89

63. Beske P, Seuring S (2014) Putting sustainability into supply chain management. Supply Chain Manag Int J 19(3):322-331 